\title{
Corporeal Ecology and European Otherness on the Shakespearean Stage
}

L'Écologie corporelle et l'altérité européenne sur la scène shakespearienne

\section{Leanore Lieblein}

\section{(2) OpenEdition}

\section{Journals}

\section{Electronic version}

URL: http://journals.openedition.org/shakespeare/754

DOI: $10.4000 /$ shakespeare.754

ISSN: 2271-6424

\section{Publisher}

Société Française Shakespeare

\section{Printed version}

Date of publication: 1 November 2005

Number of pages: 173-187

ISBN: 2-9521475-7-5

\section{Electronic reference}

Leanore Lieblein, "Corporeal Ecology and European Otherness on the Shakespearean Stage », Actes des congrès de la Société française Shakespeare [Online], 22 | 2005, Online since 01 January 2007, connection on 02 May 2019. URL : http://journals.openedition.org/shakespeare/754 ; DOI : 10.4000/ shakespeare.754 


\section{Shakespeare et l'Europe de la Renaissance}

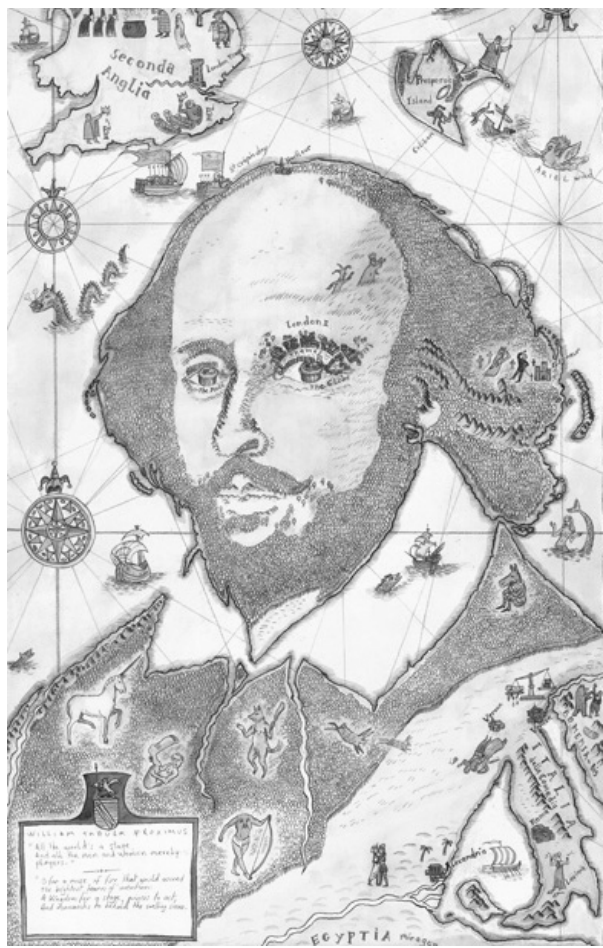

a ctes du Congrès

organisé par la

SOCIÉTÉ FRANÇAISE SHAKESPEARE

les 11,12 et 13 mars 2004

textes réunis par

Pierre KAPITANIAK

sous la direction de

Yves PEYRÉ 


\title{
COMITÉ SCIENTIFIQUE :
}

\author{
Margaret Jones-Davis \\ Jean-Marie Maguin \\ Yves Peyré \\ Pierre Kapitaniak
}

COUVERTURE :

Edouard Lekston, William Tabula Proximus, 2004

conception graphique et logo

Pierre Kapitaniak

CC 2004 Société Française Shakespeare

Institut du Monde Anglophone

Université de Paris III - Sorbonne Nouvelle

http:// univ-montp3.fr/SFS/

5 rue de l’École de Médecine

75006 Paris

ISBN 2-952 1475-1-5

Tous droits de traduction, de reproduction et d'adaptation réservés pour tous les pays 


\title{
CORPOREAL ECOLOGY AND EUROPEAN OTHERNESS ON THE SHAKESPEAREAN STAGE
}

\author{
Leanore LIEBLEIN
}

\begin{abstract}
The early modern period was one in which corporeality became an important element of what was understood as "human nature." Physician philosophers like Levinus Lemnius in The Touchstone of Complexions (English translation 1576) or Thomas Wright in The Passions of the Mind in General $(1601,1604)$ affirmed the commonality of human beings while they theorized the body as a site of difference between "nations." They saw the human organism as a complex ecological system, both internally coherent and in a subtle relationship with its environment. Different environments produced different national characteristics, but similar physiologies made adjustment and change possible. William Shakespeare employs the language of the physiologically and environmentally mediated body to explore the phenomenon of European sameness and difference. In this paper I focus on Henry $v$, which redefines the English body to incorporate its French national other, and The Merchant of Venice, which in its representation of the troubled relationship of the Venetian body to its included / excluded others, refuses the ecology of otherness.
\end{abstract}

L'Écologie corporelle et l'altérité européenne sur la scène shakespearienne Au début de la période moderne, la corporalité devint un élément important de ce qui était alors compris comme étant la "nature humaine ". Des médecins philosophes tels Levinus Lemnius dans The Touchstone of Complexions (traduction anglaise 1576) ou Thomas Wright dans The Passions of the Mind in General $(1601,1604)$ ont affirmé la nature commune des êtres humains tout en théorisant le corps comme étant un lieu de différences entre les " nations". Ils voyaient l'organisme humain comme un système écologique complexe, à la fois intérieurement cohérent et en relation subtile avec son environnement. Différents environnements produisaient différentes caractéristiques nationales, mais des physiologies similaires rendaient possibles le changement. William Shakespeare emploie le langage du corps modulé physiologiquement et environnementalement pour explorer le phénomène du pareil et du différent européen. Dans cet article, je me penche sur Henry v, qui redéfinit le corps anglais pour y incorporer son Autre national français, ainsi que sur The Merchant of Venice qui, dans sa représentation de la relation troublée du corps vénitien à ses Autres inclus / exclus, refuse l'écologie de l'altérité.

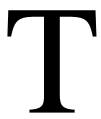

here is general agreement that the modern idea of nationhood has its roots in the early modern period. The process of emerging nationhood, particularly within the framework of the new historicist emphasis on power, is usually seen as one of differentiation. As Richard Helgerson concludes in his richly nuanced study of Forms of Nationhood, "[h]owever much [the younger generation of Elizabethans, including Shakespeare, whose writings are the focus of his study] may have resisted the centralizing forces of the monarchic state, these men helped solidify and thicken the lines that separate one nation from another." "Yet while the boundaries between nationals in Shakespeare's plays are sometimes functional, they are

\footnotetext{
${ }^{1}$ Richard Helgerson, Forms of Nationhood: The Elizabethan Writing of England (Chicago: University of Chicago Press, 1992), 300.
} 
often irrelevant. It is particularly in his representation of Europeans, in spite of the presence of stereotypical characterizations, that the otherness disappears. Can we really think of Dogberry - or, for that matter, Beatrice and Benedick - as Messinan? Could Shakespeare's contemporaries? In this paper I am in search of a theoretical model that helps us to account not only for the impulse toward differentiation, but also for the diffuseness of difference in Shakespeare's representation of his European others. I would like to complement the political discussion of nationhood and "the lines that separate one nation from another" with one in which the national other is another self, a self that could be both disquietingly same and disquietingly strange. I suggest that both the appeal of the other as other and the ease of its appropriation are rooted in an early modern understanding of national sameness and difference as both corporeal and ecological. I also suggest that by the mid-seventeenth century, the perception of national otherness had become anthropological rather than ecological.

The early modern period was one in which corporeality became an important element of what was understood as "human nature." Rhetorical treatises explored the relationship between bodily postures and the passions, physiognomical treatises suggested that one could find the mind's construction in the face, and works of moral philosophy in the period insisted that an understanding of the human subject as a moral agent required an understanding of his or her physical and animate nature. Physician philosophers in the sixteenth and seventeenth centuries also focused on the body to hypothesize national difference. Authors like Levinus Lemnius in The Touchstone of Complexions (English translation 1576) or Thomas Wright in The Passions of the Mind in General (1601, 1604) argued that an understanding of an individual's physiology, including the humours, the passions, and the complexions, was central to an understanding of the human being's moral nature and the possibility of a virtuous life. ${ }^{2}$ However, even as they sought to affirm the commonality of human beings, they found in their bodies the things that made them different from one another. Hence their enterprise was paradoxical: their claim for the universality of human nature made it possible to theorize the

\footnotetext{
2 William Webster Newbold (ed.), The Passions of the Mind in General by Thomas Wright: A Critical Edition (New York: Garland, 1986), 17.
} 
body as a site of difference between what they called "nations." Lemnius and Wright explored an ecology of national difference. For them the human organism was a complex system, both internally coherent and in a subtle relationship with its environment. Different environments produced different national characteristics, but similar physiologies made adjustment and change possible. Their perception of national difference was both corporeal and flexible. If what made nations different were the things that kept them apart, what made them the same could obviate their differences or bring them together.

In this paper I suggest that Shakespeare employs the language of the physiologically and environmentally mediated body to explore the phenomenon of national otherness. The proximity of continental Europe to England made it an ideal site for an examination of the corporeality and fluidity of national difference. I use the word "nation" as it is widely used by the sixteenth-and seventeenth-century authors whose work I discuss: to denote a recognizable (because it has in the period a familiar name attached to it) collectivity that is sometimes regional, sometimes linguistic, sometimes religious, sometimes cultural, sometimes political, and always, as John Gillies suggests when he proposes what he calls a "poetic geography," other. ${ }^{3}$

$$
* * *
$$

Comprehending the physicality of the human subject was a transnational enterprise: works were translated from Latin and European vernaculars into English and from English into other languages. ${ }^{4}$ Authors, who drew upon and acknowledged each others' work, were simultaneously aware of themselves as part of a European community in which they participated and part of a national community they represented. Thus the English Thomas Wright in The

\footnotetext{
3 John Gillies, Shakespeare and the Geography of Difference (Cambridge: Cambridge University Press, 1994), 6. Gillies defines "poetic geography" as "a paradigm for any geography that differentiates between 'us' and 'them'."

4 The following works by Dutch, French, and Spanish authors translated into English may be taken as examples: Lemnius, The Touchstone of Complexions, from Latin by Thomas Newton (1576); Pierre de La Primaudaye, The French Academie, from French by Thomas Bowes (1586); Juan de Huarte Havarro, Examen de ingenios, the examination of mens wits, from the Italian version of Camillo Camili by Richard Carew (1594); Pierre Charron, Of wisdome, from French by Sampson Lennard (1606?); and Nicolas Coffeteau, A table of humane passions, from French by Edmund Grimeston (1621). Cf. Newbold, op. cit., 17-23.
} 
Passions of the Mind in General draws upon The Touchstone of Complexions by the Dutch Lemnius and Examen de ingenios, the examination of mens wits by the Spaniard Juan de Huarte Navarro (English trans. 1594). However, the international project also had a national agenda since, as Wright indicates in his preface, among his reasons for writing his book was the virtuous deportment of Englishmen, with the advancement of their reputation among other nations. ${ }^{5}$

The perception of national difference was not just a matter of pride. It followed from the argument, elaborately developed by Wright in Book I of The Passions of the Mind, that "divers complexions are inclined to divers passions." And for Wright, as for Lemnius earlier, complexions and passions are shared by members of national groupings but differ from group to group. Indeed, Wright regrets that lack of space prevents him from developing the subject at great length: "I might discourse over Flemings, Frenchmen, Spaniards, Italians, Polans, Germans, Scottishmen, Irishmen, Welshmen, and Englishmen, explicating their national inclinations, good or bad, but every one of these exacteth a whole Chapter, and perhaps some of them, more proud than wise, would be offended with the truth" (121-22).

Lemnius has no such compunctions. Though he limits himself to paragraphs or pages rather than chapters, he distinguishes in some detail between nations and individuals on the basis of their temperaments and complexions. To give just a flavour of his argument, though the compression that follows oversimplifies, those from colder northern regions, he claims, because of their "grosse bloud and thicke Spyrites," are seen to be "bolde and full of venturous courage, rude, unmanerlye, terrible, cruell, [and] fierce." Germans, on the other hand, because their spirits are moderately cold, are "constant, stedfast, and faythfull [...] but by reason of their coldnes \& fayntnes of heate [...] [are] not very quick witted nor of very precise judgement." Hollanders, who have "moyst spirites $[, \ldots]$ are quicke and readye conceyvers [understanders] [..,] but not long retayninge the same in memorie." They are also "oblyvious, sleepie, unapte to learne Artes and occupations, dull witted and grosse headed." Spaniards, "[...] when their bloud is up, will rashlye and unadvisedlye attempte any thinge."

\footnotetext{
5 Newbold, op. cit., 27.

${ }^{6}$ Newbold, op. cit., 121.
} 
And finally, Frenchmen, because they have "thinne spirites temperatelye hoate, have sharpe and ready wittes, and prompt and flowing utteraunce." In addition, "for devyse and invention they be very sharpe and ingenious [and] for brave settinge oute and beautifyinge of a matter, plentyfull and copious: and [...] as for the explayning of their meaninges and purposes have talke and tongue at will." They are also "lively felowes, [...] dapper, nimble, lackinge no grace of pleasaunte gesture."7

Wright's forecast of objections to his own potential description of national otherness, were he to embark upon it, is perhaps a reflection of his own experience, since he himself reacts grudgingly to a negative comparison of the English to the Italians in Lemnius. According to Lemnius, Italians are "perfused wyth temperate moisture and heate" and therefore in their dealings, "watchfull, sharpe, industrious, in [...] quicknes of wit, industry of nature, excellencie of learninge, notable utteraunce, and flowinge eloquence, surpassing other men." They do not, however, relinquish a grudge and a desire for revenge. Englishmen, says Lemnius, are similar to Italians, but "being of heate more weake and lesse boylinge, [...] are of stature comely and proportionable [...]." They are, however, less given to the arts than the Italians and are capable of great anger (17v-18). In reply Wright writes, "I must confess that in some one or other trade the Italians surpass us, but they be such as either England regardeth not at all or prizeth not very much; but in such as our Country esteemeth we may either equal or prefer ourselves before them" (121).

Both Lemnius and Wright in their characterizations of national difference assert a relationship between geography, physiology and affect. As Wright writes, "the same causes [such as climate] which concur to the framing of such a constitution serve also to the stirring up of such a passion" (121). They are not, however, invoking a genetic or environmental determinism, since both insist that undesirable behaviours caused by geographical circumstances are not without remedy. Insight into their causes helps one understand how to change them. For Lemnius, his generalizations are not judgments but designed to produce awareness of possibilities for change and improved health:

\footnotetext{
${ }^{7}$ Levinus Lemnius, The Touchstone of Complexions, trans. Thomas Newton, (London, 1576), 13-20 [STC (2nd ed.) 15456]. I have reproduced the original spelling, but modernized typography.
} 
Seeing therefore, the diversitie of spirits, and the differences of wittes and maners proceedeth of the condition and nature of the Place, Ayre, Countrey and nourishmente, let every man foresee in himself, which way he may best provide for the maintenaunce of his health, and to shunne all such thinges as may in any wise harme, annoye, crushe, or empaire either his health or Spirits. (20)

Evidence of the ability to overcome the effects of things like "Place, Ayre, Countrey and nourishmente" is provided by the example of Prince Erik, king of Sweden, who in spite of the fact that those born near the "Pole Articke \& ycie Sea [...] for the most part are very huge \& stronge bodyed, but for witte and learning, mere doltes \& Asseheads," was able to create a "Nacion ... nowe trayned to more civill order" (16). Clearly nurture, for Lemnius, is just as important as nature.

This capacity for change allows members of nations not only to distinguish themselves from other nations, but also to accommodate and learn from members of other nations in a context of both intellectual and economic exchange. Nations are different, but their difference is predicated on their sameness, since though they come from or live in different places, all are subject to the "condition and nature of the Place, Ayre, Countrey and nourishmente," from which they come. In addition, both Lemnius and Wright make it clear that the national differences they propose are generalizations. They are descriptions of group behaviours which are statistically significant because observable of large numbers of countrymen, even though at the individual level the behaviours described can in fact be changed through such things as education and diet. In other words, they are at least as significant rhetorically as they are physiologically or morally. What is important therefore is not whether the descriptions are accurate or what the distinctions tell us about the different nationalities (though it is remarkable how many of the generalizations have persisted and congealed into national stereotypes), but the belief that there are cultural differences that can be attributed to members of different nations, that these differences can under certain circumstances be obviated, and that at the heart of the difference lies corporeality. In the discussion that follows I illustrate the ecology of otherness in Shakespeare's Henry $V$, which redefines the English body to incorporate its French national other. I then briefly look at The Merchant of Venice as an example of a play which refuses the ecology 
of otherness and represents the troubled relationship of the Venetian body to its included/ excluded others.

A central preoccupation of Shakespeare's Henry $V$ is the ecology of English nationhood. At one level, following Lemnius and Wright, the English nation is a product of such things as its geography, climate, and diet: "And you, good yeomen, / Whose limbs were made in England, show us here / The mettle of your pasture," urges King Henry before the walls of Harfleur (III.i.25-27). ${ }^{8}$ The French too acknowledge their rivals in terms of such elements, though they read the elements differently:

Dieu de batailles! where have they this mettle?

Is not their climate foggy, raw, and dull,

On whom, as in despite, the sun looks pale,

Killing their fruit with frowns?

[...] O, for honor of our land,

Let us not hang like roping icicles

Upon our houses' thatch, whiles a more frosty people

Sweat drops of gallant youth in our rich fields!

(III.v.15-18, 22-25)

And Henry himself, when he boasts to Montjoy, finds that he is altered by the fields of France: "Yet forgive me, God, / That I do brag thus! This your air of France / Hath blown that vice in me" (III.vi.150-52).

But just as Lemnius and Wright themselves recognized, though environmental factors such as climate or diet can influence the passions, spirit or blood, they can also create expectations that are not fulfilled. Thus the treachery of Lord Scroop, who seemed to embody the reliability of those men who are "spare in diet, / Free from gross passion, or of mirth or anger, / Constant in spirit, not swerving with the blood" (II.ii.131-33), has thrown the relationship between environment, physiology, and political morality open to question. The lesson of Lord Scrooop and the other traitors is that geography and its accompanying physiology are accidents of nationhood which are meaningless without commitment. As Lemnius and Wright argue, and as the passages from Henry $V$ cited above illustrate, one can adapt to or

\footnotetext{
8 All quotations from Shakespeare's plays are from The Riverside Shakespeare, ed. G. Blakemore Evans et al. (Boston: Houghton Mifflin, 1974).
} 
overcome the contingencies of geography. It takes more than English birth to make an Englishman.

Thus Henry's army consists not only of the English Gower, but also of the Welsh Fluellen, the Irish Macmorris, and the Scottish Jamy. However, their participation in the shared enterprise of England's war on France reveals the ambiguity of nationhood. They are loyal subjects who nevertheless claim their own otherness (consider, for example, Fluellen's pride in being Welsh), and bring with them, in the form of their names, their accents, their traditions, and their mannerisms, their association with nations which had in fact historically resisted colonization by England. The issue of nationhood is a matter of some sensitivity, neither straightforward nor uncomplicated:

FLU. Captain Macmorris, I think, look you, under your correction, there is not many of your nation-

MAC. Of my nation? What ish my nation? Ish a villain, and a basterd, and a knave, and a rascal. What ish my nation? Who talks of my nation?

(III.ii.120-24)

Of course we do not know how Fluellen would have completed his sentence: "[T] here is not many of your nation _-" who... what? Would it have been flattering? Disparaging? What is the relevance of Macmorris's Irishness, assuming that is what Fluellen means by the phrase "your nation" (remember John Gillies' reminder that the word always implies otherness), to the issue of the conduct of the war which is under discussion?

The heated response of Macmorris challenges the presupposition that Fluellen (or the spectator, for that matter?) knows Macmorris's nation. Is Macmorris denying Fluellen's implication that he is Irish and implying that he is as English as the next man? Or denying the right of anyone other than himself to decide what his nation is? And what does he mean when he says his nation "ish a villain, and a basterd, and a knave, and a rascal"? Is he, as a captain in the English army, distancing himself from the traditionally negative characterizations of the Irish by the English? Or is he, as an English captain, recognizing that the English nation is not all it's cracked up to be ${ }^{9}$

${ }^{9}$ David Cairns and Shaun Richards, Writing Ireland: Colonialism, Nationalism and Culture (Manchester: Manchester University Press, 1988), 10, read "What ish my nation?" as "a rhetorical question to which the answer is supplied by Macmorris's service in the 
If the English nation is composed of many nations, those nations are not only territorial like the Welsh, the Scots, and the Irish. Other contemporary uses of the word nation, such as the "nation" of roarers, or the "nation" of fools, or the "nation" of people who regularly visit prisoners, ${ }^{10}$ suggest the sociological dimension of the term in the period. The dialogue between Fluellen and Macmorris is preceded by a demonstration of the cowardice and corruption of Nym, Bardolph, and Pistol, who might well stand for the "villain," or "basterd," or "knave," or "rascal" alluded to by Macmorris, and who are also members of the English nation. The English nation is composed both of collectivities and of individuals, some of them captains and some of them cowards, some of them "of name" and some of them not "of name" as in the list of war dead (IV.viii.105), some of them indeed corrupt and some of them rich in integrity like the Boy who serves Bardolph, Nym and Pistol and sees through them and dies with other boys protecting the luggage of the camp.

Thus the medieval notion of the "King's Two Bodies"11 gets redefined. The King's "body politic" not only represents the kingdom but depends on its materialization in its population. The Prologue begins the play with a univocal definition of both England and France: "Suppose within the girdle of these walls / Are now confin'd two mighty monarchies" (PRO.19-20). And yet a monarchy is mighty only by virtue of the many bodies that compose it: "Piece out our imperfections with your thoughts; / Into a thousand parts divide one man, / And make imaginary puissance" (PRO.23-25). Similarly, the King's "body natural" takes its significance from the fact that not only is the King a man, but that he is a man like other men: "For though I speak it to you, I think the King is but a man, as I am. The violet smells to him as it doth to me; the element shows to him as it doth to me; all his senses have but

English army." For them the scene demonstrates the incorporation of barbaric and resisting others into the English nation while maintaining through language, uncouthness and rank their subordinate status.

${ }^{10}$ For examples see Ben Jonson, Volpone in Ben Jonson: Four Comedies, ed. Helen Ostovich (London: Longman, 1997), I.ii.76, and Thomas Dekker, English Villainies Discovered by Lantern and Candlelight, in Thomas Dekker: Selected Prose Writings, ed. E. D. Pendry, Stratford-upon-Avon Library 4 (London: Edward Arnold, 1967), 268. My thanks to Pascal Clottes for the Dekker reference.

${ }^{11}$ For an overview see Ernst H. Kantorowicz, The King's Two Bodies: A Study in Mediaeval Poliltical Theology (1957; reprint, Princeton: Princeton University Press, 1997). 
human conditions. His ceremonies laid by, in his nakedness he appears but a man" (IV.i.100-105).

The ecology of English nationhood in Henry $v$ is represented as organic and corporeal. It is a product of place but also of persons, of the one but also of the many. It can in addition embrace and incorporate the other, and is subject to change. The French nation, as we have seen above, is similarly a product of its environment. However, England has conspicuously, by the admission of the French, adapted to the French milieu:
Can sodden water,
A drench for sur-rein'd jades, their barley-broth,
Decoct their cold blood to such valiant heat?
And shall our quick blood, spirited with wine,
Seem frosty?

(III.v.18-22)

Such adaptability is sexually potent: "Our madams mock at us, and plainly say / Our mettle is bred out, and they will give / Their bodies to the lust of English youth / To new-store France with bastard warriors" (III.v.28-31).

Thus the union of England and France at the end of the play, though the outcome of military victory and hard-headed negotiation (an earlier offer of Katherine in marriage and a dowry of "[s]ome petty and unprofitable dukedoms" had been rejected [III. CHO. 31-32]), is a physical union that will reinvigorate a feminised French body as well as a political union. ${ }^{12}$ The union of England and France has the potential to enlarge both countries: "Take her, fair son, and from her blood raise up / Issue to me, that the contending kingdoms / Of France and

\footnotetext{
12 The French body in the form of the princess Katherine is eroticised. Her English lesson partitions Katherine's body and makes it sexually available:

Le foot et le count! O Seigneur Dieu! ils sont les mots de son mauvais, corruptible, gros, et impudique, et non pour les dames de honneur d'user. Je ne voudrais prononcer ces mots devant les seigneurs de France pour tout le monde. Foh! Le foot et le count! (III.iv.52-56)

Nevertheless, she does accept to repeat all the words that signal her sexual subjection. I have omitted from the discussion Exeter's opportunistic assertion to the French King that "law of nature and of nations" (II.iv.80) justifies Henry's claim to the French throne, since the relationship between "nature" and "nations" being asserted here is far from the ecological one I have been discussing. The same is true of Hector's use of the phrase ("these moral laws / Of nature and of nations speak aloud") when he argues for the return of Helen because she is wife to Sparta's king (Troilus and Cressida, II.ii.184-5).
} 
England, whose very shores look pale / With envy of each other's happiness, / May cease their hatred" (v.ii.348-52). ${ }^{13}$

$$
* * *
$$

The sense of another nation as an extension of the self depends on a willingness to see the other, though the product of a different milieu, as equally human; in other words, in the context of Wright and Lemnius, equally a product of physiology and environment. The thriving economy of Venice in The Merchant of Venice depends on just such a view of the nations who participate in its economic life. For example, to Solanio's observation that the Duke would never permit Shylock to exact his terrible forfeit Antonio replies,

The Duke cannot deny the course of law;

For the commodity that strangers have

With us in Venice, if it be denied,

Will much impeach the justice of the state,

Since that the trade and profit of the city

Consisteth of all nations.

(III.iv.26-31)

The dilemma of The Merchant of Venice lies in the ambiguous triangulated relationship between strangers (those members of "all nations" who contribute to "the trade and profit of the city"), the Venetian body politic ("the justice of the state"), and the Venetian body (Shylock's pound of flesh). However, in the play, because he is denied corporeal sameness, Shylock is excluded from the company of nations.

Among the strangers in the play are Portia's suitors, identified by Nerissa in terms of their "nation," and described by Portia in terms of their temperaments, much in the fashion of Lemnius. These include the Neapolitan prince, the County Palentine [sic], the French lord, the young baron of England, his neighbor the Scottish lord, and the young German. What distinguishes Bassanio, mentioned as an afterthought, is the fact that he is a Venetian. That Portia excludes certain bodies from the human community, however, is evident in her comment on the Prince of Morocco: "If he have the condition of a saint, and the complexion of a devil [in other words, if he be black], I had rather he should shrive me than wive me" (I.ii.129-31). Morocco's racial

\footnotetext{
13 History, of course, tells us, and the Chorus / Epilogue of Henry V points out, that what follows is the loss of France by England under Henry VI.
} 
otherness, which becomes a trope of physical and national otherness, is insisted upon. He is described in the quarto and folio stage directions at the top of Act II, scene one as "a tawny Moor, all in white," and while not a European, crystallizes the issues that will be central to the perception of Shylock's otherness:

Mislike me not for my complexion,

The shadowed livery of the burnish'd sun,

To whom I am a neighbor and near bred.

Bring me the fairest creature northward born,

Where Phoebus' fire scarce thaws the icicles,

And let us make incision for your love,

To prove whose blood is reddest, his or mine.

In spite of the colour of his skin, Morocco claims for himself an essential humanity that he shares with other nations. His blood is as red as that of any Venetian.

Shylock's corporeal otherness precedes him into the world of the play by virtue of visual and theatrical traditions associating the representation of Jewishness with the orange wig of Judas; other features include the gabardine and head covering, and mannerisms of speech, posture, and gesture. But he too, like the Prince of Morocco, insists on his corporeal sameness:

Hath not a Jew eyes? Hath not a Jew hands, organs, dimensions, senses, affections, passions; fed with the same food, hurt with the same weapons, subject to the same diseases, heal'd by the same means, warm'd and cool'd by the same winter and summer, as a Christian is? If you prick us, do we not bleed? If you tickle us, do we not laugh? If you poison us, do we not die?" (III.i.59-66)

The Venetian body is exemplified by Antonio, the merchant whose ventures represent "the trade and profit of the city." His melancholy affect is a complexion in the sense that Lemnius uses the term in his Touchstone of Complexions, and quite different from the alternative constructions of the body offered in the opening scene by Antonio's friends. Solanio speaks of "Some that will evermore [...] laugh like parrots at a bagpiper; / And other of such vinegar aspect / That they'll not show their teeth in way of smile ..." (I.i.52-55). But like Shylock's later "Some men there are love not a gaping pig; / Some that are mad if they behold a cat" (IV.i.47-48) in justification of his animus against Antonio, such an account of human behaviour focuses on eccentricity rather than commonality, and on rigidity rather than flexible 
accommodation. Gratiano describes "a sort of men whose visages / [...] do a willful stillness entertain, / With purpose to be dress'd in an opinion / Of wisdom, gravity, profound conceit ..." (I.i.88-92). But like Bassanio's thoughts on the deceptiveness of external appearances as he makes his choice of the leaden casket, such an account sees affect as pretence and deception. For himself Gratiano chooses another body: "Let me play the fool, / With mirth and laughter let old wrinkles come" (I.i.79-80). There is a difference, however, between a choice of lifestyle and the physiological consequences of "Place, Ayre, Countrey and nourishmente" that characterizes the passions and complexions discussed by Wright and Lemnius. None of these bodies are Antonio's. $\mathrm{He}$ even refutes the plausible suggestion of Solanio and Solario that his sadness is an internalization of the uncertain fortunes of his spice and silk-laden argosies, or, failing that, an expression of unrequited love. Antonio's sadness cannot be linked to his own idiosyncrasies or personal preoccupations because it represents the malaise of Venice itself. Like Venice, his trade and profit result, as we saw above, not only from Venetians but from "strangers ... of all nations." His personal identity and integrity is dependent upon the other "nations" that contribute to his professional identity. ${ }^{14}$ But he is alienated from himself because he is ill at ease with and ultimately threatened by Shylock whom he refuses to see as a member of the community of nations.

Shylock's bond is an assault on the Venetian body that has "scorn'd [his] nation" (III.i.56) and denied his humanity: "You call me misbeliever, cut-throat dog, / And spet upon my Jewish gabardine, [...] You, that did void your rheum upon my beard, / And foot me as you spurn a stranger cur" (I.iii.111-12, 117-18). When flesh does not signify humanity, it becomes commodity: "A pound of man's flesh taken from a man / Is not so estimable, profitable neither, / As flesh of muttons, beefs, or goats" (I.iii.165-67). And if flesh cannot serve to turn a profit, it can serve "to bait fish withal" (III.i.53). Shylock becomes what he has been told he is: "Thou call'dst me dog before thou hadst a cause, / But since I am a dog, beware my fangs" (III.iii.6-7).

\footnotetext{
14 Antonio's melancholy in I.i may be contrasted with Portia's weariness which parallels it at the beginning of the following scene: "By my troth, Nerissa, my little body is a-weary of this great world" (I.ii.1-2). Portia explicitly relates her state of mind to her situation.
} 
Both Shylock and Antonio participate in what is called "commodity" in Venice. They are not, however, both Venetians. Shylock is, in the word used by Portia, an "alien" (IV.i.349) and, as Antonio would have it, irretrievably other:

You may as well forbid the mountain pines

To wag their high tops, and to make no noise

When they are fretten with the gusts of heaven;

You may as well do any thing most hard

As seek to soften that $\longrightarrow$ than which what's harder?-

His J ewish heart!

(IV.i.75-80)

Shylock's difference, in Antonio's characterization of him, is not, as Lemnius or Wright would have it, a complexion or a passion, influenced by such things as physiology, environment, religion, and tradition, whose consequences are negotiable; his difference is represented as essential and unchangeable, and by virtue of his dehumanisation, he is excluded from the community of nations. ${ }^{15}$

$$
* * *
$$

In 1650 John Bulwer published Anthropometamorphosis, subsequently printed with the title A View of the People of the Whole World. ${ }^{16}$ It offered a survey of the world's nations in terms of their corporeal differences. Like The Touchstone of Complexions and The Passions of the Mind in General, Anthropometamorphosis walks the fine line between assuming the sameness of the world's peoples and observing their otherness in different local circumstances. Nevertheless, Bulwer's work reveals a profound change that has occurred in the perception of national otherness.

Bulwer starts with an assertion of universal and perfect original created by God and shared by all nations, but what interests him, even more than Lemnius and Wright, are the local variations. $\mathrm{He}$ is enthralled by the diversity he describes. He may denounce the deformations of the body pictured in his book as transgressive in principle, but he puts them on display because these "nationall

\footnotetext{
15 Even when Wright in Book v of The Passions of the Mind in General, which addresses "The means to move Passions," does discuss the question of arousing passions against those who are different, he sees those differences as "natural dispositions" of the kind that he has said are subject to change (op. cit., 281).

$16 \mathrm{~J}$ ohn Bulwer, A View of the People of the Whole World, (London, 1654) [Wing B5470].
} 
monstrosities" (275), as he calls them, are fascinating in practice (the book contains over a hundred extraordinary illustrations). Individual chapters discuss, just to cite a few, "Fashions of the Head," "Fashions of Haire," "Eye-lid Fashions," "Auricular Fashions," "Artificial Scars," "Mouth Fashions," "Lip-gallantry," "Dentall Fashions," "Humerall, or Shoulder-Affectations," "Pap-Fashions," and "Leg and Foot-fashions."

The use of the word "fashions" is revealing. Bulwer claims to be scandalized - the word "monstrous" frequently recurs - by the invasiveness of such fashion of what he calls, after Vesalius, the "human fabric." But although such extreme interventions as scarring, tattooing, alterations to the bone structure, even amputation, are shocking, as "fashions," they are represented as acts of cultural choice which are attributed in every case not only to individuals but simultaneously to members of a "nation." They are different in degree but not in kind from what, in an appendix titled "the Pedigree of the English Gallant," are described as the "fashions" frequently attributed to gallants in Jacobean city comedy. Though intensely corporeal, they are acts of self-representation.

For Lemnius and Wright the otherness of nations is ecological. It is the fruit of a subtle interaction between physiology, environment, and culture, and because it is interactive, it is subject to change. For Bulwer who positions himself as an observer rather than as a philosopher, such otherness is anthropological. The corporeal differences described by Bulwer, though they come from all over the world, do not have the environmental dimension so important to Lemnius and Wright. While they presumably can be changed, Bulwer, unlike Lemnius and Wright, does not perceive such change in terms of the delicate adjustment and negotiation implicit in the model of the body's sensitivity to its physical and cultural environment. Unlike the "nationall monstrosities" pictured by Bulwer, for whom otherness is fascinating because it is grotesque and bizarre and confirms difference, Shakespeare's European others have the potential to be same as well as different, have the potential to change and be changed, and also have the potential to be denied that potential and to be excluded as well as included. 